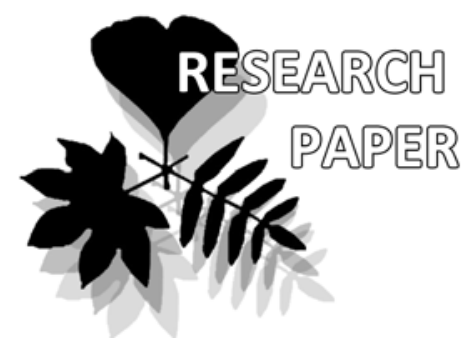

\title{
Does Gymnomitrion corallioides Nees (Hepaticae) occur in temperate East Asia?
}

\author{
Vadim A. Bakalin
}

Vadim Bakalin *

e-mail: vabakalin@gmail.com

Botanical Garden-Institute FEB RAS, Vladivostok, Russia

Manuscript received: 10.02 .2016 Review completed: 26.03.2016 Accepted for publication: 04.04.2016 Published online: 06.05.2016

\begin{abstract}
A B S T R A C T
Based on study of type materials and other available specimens it is suggested that in Hemiboreal and Temperate East Asia Gymnomitrion corallioides is replaced throughout by closely related, but nevertheless different $G$. faurianum, treated for the last 50 years as the synonym of the former. These two species as well as related $G$. laceratum are described and illustrated based on study of type materials. A paper provided the key to identify Gymnomitrion taxa in extra-tropical Pacific Asia (excluding recently transferred Apomarsupella and relatives) as well as an overview of distribution patterns for some taxa of the genus.
\end{abstract}

K e y w o r d s : Gymnomitrion, Hepaticae, new taxa, taxonomy, East Asia, the Russian Far East

\section{P E 3 Ю M E}

Бакалин В.А. Встречается ми Gymnomitrion corallioides Nees (Hepatiсае) в умеренной Восточной Азии? На основании изучения типовых и прочих материалов показано, что в гемибореальной и умеренной Восточной Азии Gymnomitrion corallioides замещается близким, но самостоятельным $G$. faurianum, рассматривавшимся на протяжении последних 50 лет в качестве синонима первого. А^я обоих видов, а также морфологически родственного $G$. laceratum даны описания, состав енные на основе типовых материалов, а также илАюстрации. Приводится кАюч Аля определения видов Gymnomitrion во внетропической Восточной Азии (исключая недавно перемещенные Apomarsupella и родственные ему таксоны) и очерк закономерностей распространения некоторых видов рода.

К к ю че вы е с м ов а: Gymnomitrion, Hераticae, новые таксоны, таксономия, Восточная Азия, российский Аамьний Восток

\section{INTRODUCTION}

Gymnomitrion corallioides Nees is an Arctic Montane circumpolar liverwort that, however, was reported from far southwardly situated areas in Temperate Asia like Korean Peninsula and Japan (Yamada \& Choe 1997, Yamada \& Iwatsuki 2006). Basing on those reports I expected its presence in southern portion of the Russian Far East in the land closely adjacent to aforementioned countries northward. However, in the course of more or less detailed researches I was unable to find any plants that could be referred to this species throughout the high elevations of southernmost tips of Sakhalin, southern Kurils and southern portion of Sikhote-Alin mountain system. Thus I was surprised by this gap that is difficult to explain from phytogeographic point of view.

On the other hand, when I worked in southern half of the Russian Far East I found a lot of specimens containing plants tentatively named as Gymnomitrion concinnatum (Lightf.) Corda and those fallen into two group of 'modifications'. One of them in all characters coincides with 'modifications' from Northeast Asia and northern Europe. It is characterized by more or less vermicular or only slightly dorsiventrally compressed branches and brownish to yellowish brown color. Another group contained strongly dorsiventrally compressed and distichously leaved plants whitish in color. The latter form was dominant among species of the genus in southern part of the Russian Far East, especially in South Kurils. Before I called them (in the absence of enough material) as 'mod. albescens' of G. concinnatum (Bakalin et al. 2009, 2012). To identify the status of the latter 'modification' was the main goal of the present account.

\section{RES U LTS}

Starting from 2008, in the course of researches in South Korea and Japan, I found 'mod. albescens' quite common in those lands too. Along with that result I was stressed by the fact that I never found Gymnomitrion corallioides in Korea, from where it was several times recorded. After herbarium searches I found the plants I referred to ' $G$. concinnatum mod. albescens' are kept under $G$. corallioides (the species very familiar for bryologists in northern Eurasia) in both Korean and Japanese herbaria. The main differences between 'mod. albescens' and G. corallioides were observed in leaf apex features, papillose leaf cuticle along lobe margin and much 
softer texture. The 'tradition' to recognize it as G. corallioides appears to be started from Kitagawa (1963), who ascribed to the latter acute and crenulate lobes and papillose leaf cuticle in the morphological description. Below his morphological description he (l.c.: 110) compared it with G. obtusum (why with this species?, probably misprinting for G. corallioides? - VB) and wrote: "the leaf-lobes vary in shape, from acute to nearly obtuse, but none of them is so round in Japanese plants as those of G. obtusum in Europe and N. America”.

In my experience in Northest Asia, G. corallioides is the species of wet stony substrata in tundra zone or belt (not the same with Japanese 'alpine' belt that means Pinus pumila crooked forests and should be rather called as subalpine or krummholz), commonly growing near glaciers or snowbeds - the habitat not present in Japan. Even in East Kamchatka, that is 20 latitudinal degrees northward of middle Honshu, this species commonly does not descend below $1500 \mathrm{~m}$ alt. Noticeable, aforementioned ' $G$. concinnatum mod. albescens' (= G. corallioides sensu Kitagawa) was never observed there, as well as in adjacent Magadan Province and in northern half of Khabarovsk Territory. Contrary, Korean and Japanese 'forms' of $G$. corallioides (as they were named in the herbarium) occurs mostly in crooked forest belt and even in well developed and tall in height dark coniferous mountain forests (called in Korea and Japan as 'subalpine'). Northward these 'forms' unexpectedly (if to regard them as modifications of $G$. corallioides) disappear after $45-48^{\circ} \mathrm{N}$ and therefore has temperate western Pacific distribution.

Taking into account noted distribution gap and striking contrast in the phenotype I suggested it may be different taxa and then searched for the name for 'mod. albescens' among supposed synonyms indicated by Kitagawa. I checked the holotypes of Acolea fauriana Steph., Lophozia ubayuensis Steph. (both are in G) and Gymnomitrion corallioides Nees (STR). Then I found the holotypes of two former contain identical plants (Acolea fauriana having priority) and also are identical with puzzling 'mod. albescens' from temperate East Asia. Plants of the latter taxon were strongly different from that in the type of Gymnomitrion corallioides.

Although I cannot state definitely that $G$. corallioides is completely absent in temperate East Asia, I suggest the latter, even if present, should be very rare there, occurring, probably in very limited number of localities having the refugial value.

Below I provide the descriptions these species as well as related and still poorly understood $G$. laceratum based on type materials I studied recently. After species descriptions I provide the list of selected specimens examined for studied taxa.

1. Gymnomitrion corallioides Nees Naturgeschichte der Europäischen Lebermoose 1:118. 1833. (Fig. 1: A-E)

Lectotype: Mädelsteinen (STR!) selected by R. Grolle (1976)
Description based on the type: Plants like 'coral', as it reflects by the name, rigid, dorsiventrally compressed, vegetative branches clavate, appear from scale-like leaved rhizome, normally leaved branches $625-750 \mu \mathrm{m}$ wide and 3-6 mm long, without or with a few rhizoids, not translucent when wet; rhizome 5-10 mm long, easily branched, with a few to numerous, nearly colorless rhizoids, with branches of rhizome structure or giving the start to leaved shoots gray in color. Leaves of vegetative shoots densely imbricate, transversely inserted, obliquely spreading and transversely oriented, nearly ovate to ellipsoidal when flattened in the slide, with strongly discolored margin and grayish to brownish inward, 575-675 $\times 500-600 \mu \mathrm{m}$, divided by widely $\gamma$-shaped sinus descending to $1 / 12-1 / 10$ of leaf length into rounded lobes. Midleaf cells 22.5-32.5 $\times$ 20.0-25.0 $\mu \mathrm{m}$, thin-walled, with moderate or (mostly) large trigones, cuticle smooth; cells along margin very thin-walled in 1-2(3) rows along margin, easily erose, 10-15 $\mu \mathrm{m}$ along margin; inward suddenly become thick-walled, with large and sometimes confluent trigones.

Comment. In Pacific Asia this species is going as far to South as up to $53^{\circ} \mathrm{N}$. Southward of this latitude it occurs in two rather isolated and unique localities: 1) Tardoki-Yani Mts. - an excellent example of refugium of Beringian flora, as it was discussed before (Bakalin 2015); 2) the atrium of Tyatya Volcano in Kunashir Island, the only locality of the species within temperate zone that situated, where the species occurs in old lava clinker in rather special place having no analogues in South Kurils (very severe wind regime, late September snow melting) and also the place for a lot of other 'northern' hepatics (cf. Bakalin et al. 2009). Despite presence of relatively suitable habitats in northern Sakhalin, this species was not found there in the course of special searches. The basic habitats of the species are moderately moistened cliffs and fine soils between gravel (also near snowbed) strictly in alpine belt. As exception the species may descend to crooked forests in Hemiarctic in northern coast of sea of Okhotsk (where nevertheless occurs in gravelly barrens), and heathlands formed under very severe wind impact in Commanders and East Kamchatka. Morphologically $G$. corallioides is characterized by very shortly divided leaves, rounded lobes, smooth leaf cuticle and leaf margin cells with thin walls free of trigones.

2. Gymnomitrion faurianum (Steph.) Horik. Acta Phytotaxonomica et Geobotanica 13: 212. 1943. (Fig. 1: F-L; fig. 2: A, B)

Basionym: Acolea fauriana Steph. Species Hepaticarum 2: 8. 1901.

Holotype: "Japonia, Tidesan" Leg. U. Faurie 212, 29 August 1898. (G00067200/15025!)

Synonym: Lophozia ubayensis Steph. Species Hepaticarum 6: 111. 1917 (Holotype G00067199/15397!) .

Figure 1 Gymnomitrion corallioides Nees: A - lectotype label (STR); B - plant habit, from lectotype (STR); C - leaf margin, Mag-30-11-11 (VBGI); D - leaf lobe apex, Mag-30-11-11 (VBGI); E - plant habit, Mag-30-38-14 (VBGI). Gymnomitrion faurianum (Steph.) Horikawa: F - holotype label (G); $\mathrm{G}$ - plant habit, from holotype $(\mathrm{G})$; $\mathrm{H}$ - plant habit in the slide, from holotype (G); I - leaf margin, from holotype (G); J - lobe apex, from holotype $(\mathrm{G})$; K - bract apex, from holotype $(\mathrm{G}) ; \mathrm{L}$ - midleaf cells with oil-bodies, K-78-3-15 (VBGI). Scales a - $2 \mathrm{~cm}$ for B, G; a - $1 \mathrm{~cm}$, for E, $\mathrm{H} ; \mathrm{b}-100 \mu \mathrm{m}$, for $\mathrm{C}, \mathrm{D}, \mathrm{I}, \mathrm{J}, \mathrm{L} ; \mathrm{c}-500 \mu \mathrm{m}$, for $\mathrm{K}$ 

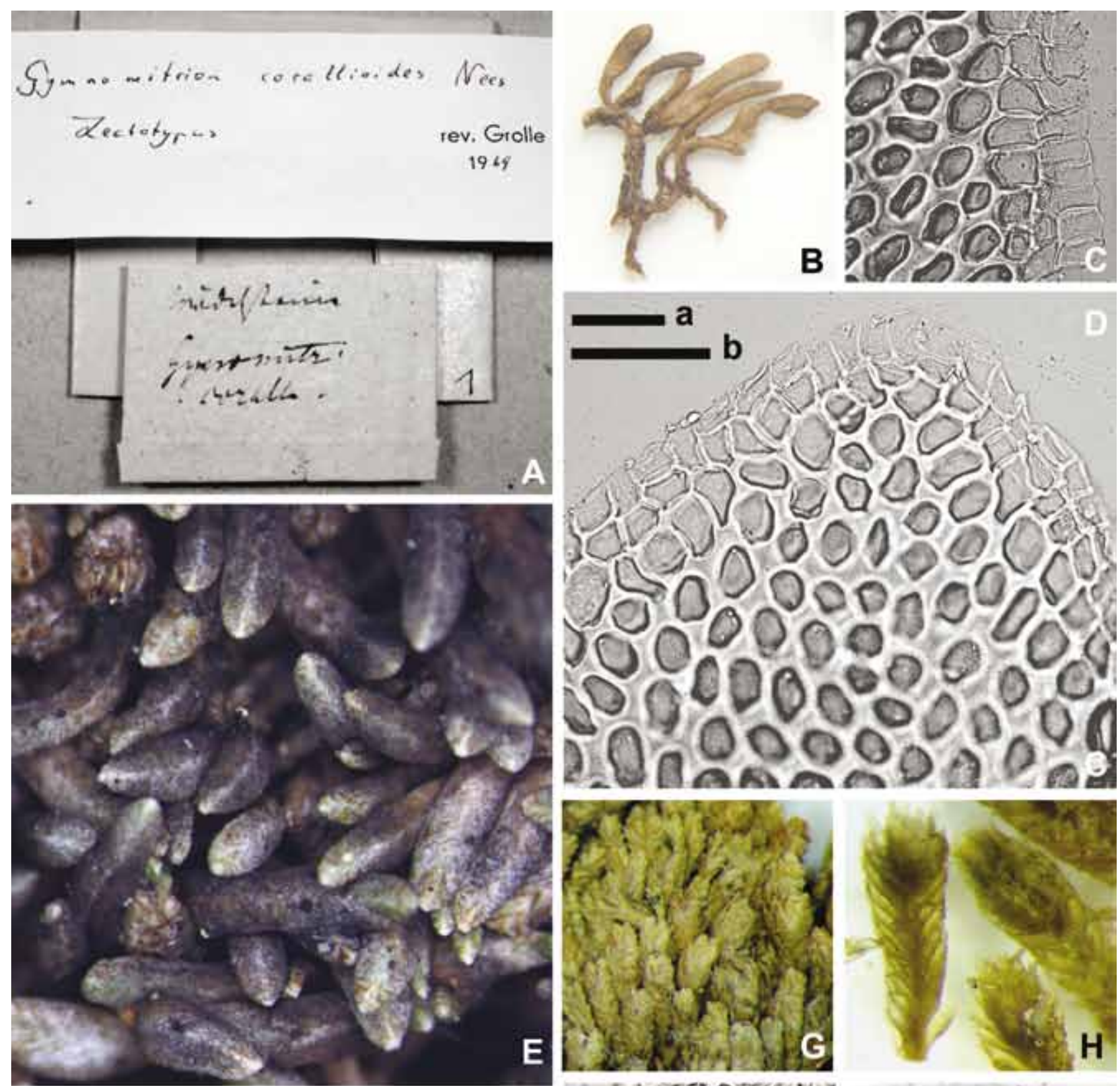

D)

A
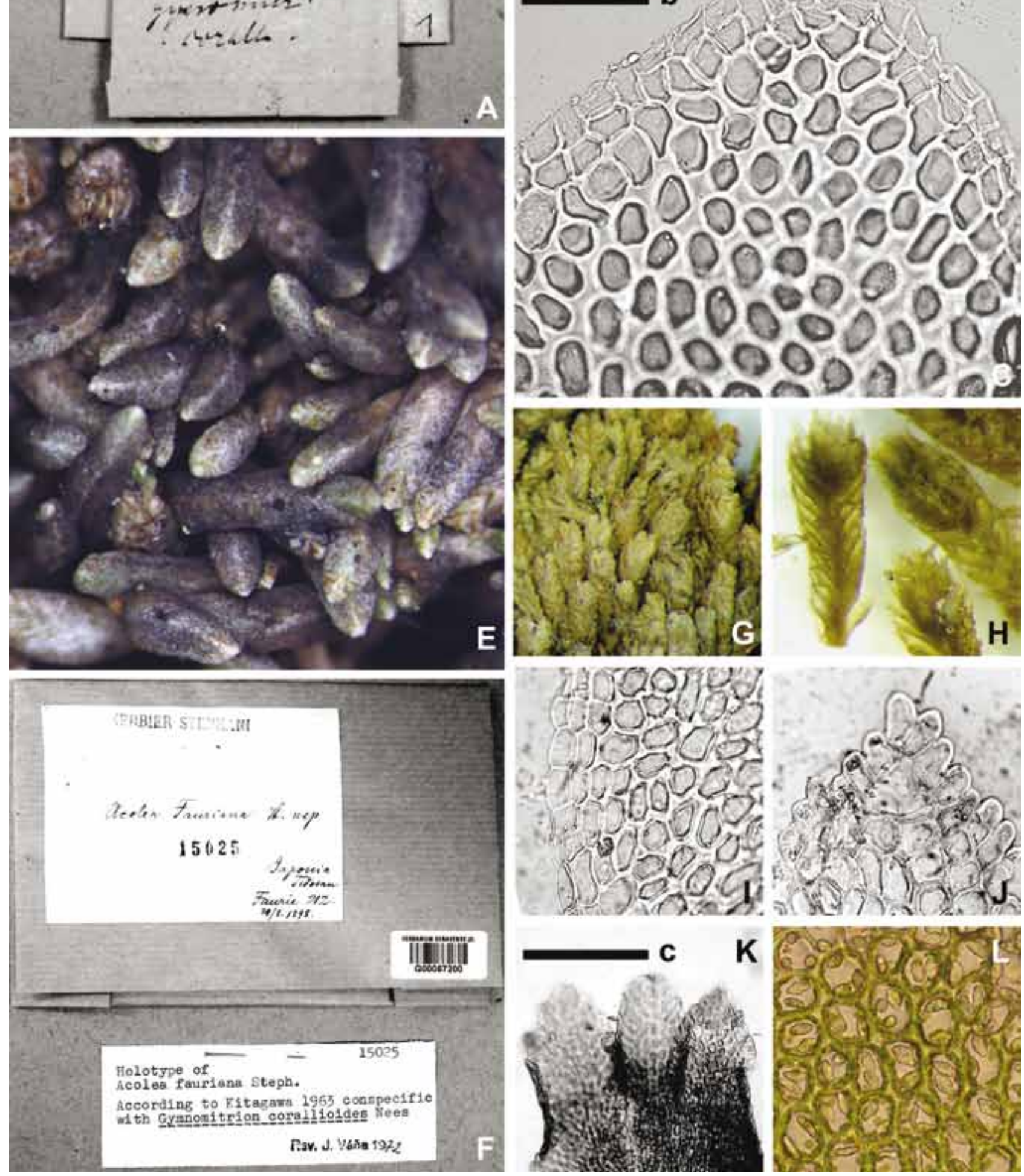
Description based on the type of Acolea fauriana: Plants merely soft, grayish to pale yellowish and pale brownish, strongly dorsiventrally compressed, forming more or less dense to loose patches, $500-800 \mu \mathrm{m}$ wide (slightly wider near perianth) and 5-8 $\mathrm{mm}$ long, translucent when wet; rhizome poorly developed. Rhizoids virtually absent to very sparse, separated, colorless, obliquely to erect spreading. Leaves transversely inserted, densely imbricate (but not so dense as in G. concinnatum or G. corallioides), obliquely spreading, transversely oriented, concave-canaliculate, 650-800 $\times$ $600-750 \mu \mathrm{m}$, nearly ovate, divided by $\mathrm{V}$ - to loosely $\gamma$-shaped sinus descending to $1 / 5-1 / 4$ of leaf length into 2 triangular to slightly gibbous acute lobes. Midleaf cells $20-32 \times$ 20-31 $\mu \mathrm{m}$, shortly oblong, thin-walled, with moderate in size, slightly convex trigones, cuticle smooth; cells in lobe margin thin- to slightly thick-walled (especially in external wall), with moderate to large, concave trigones, leaf margin distinctly crenulate near lobe apex, cuticle very finely verrucose or almost smooth; cells along margin in middle part of leaf side very thin-walled, margin nearly entire to loosely crenulate, sometimes with small trigones, in 1-2 rows commonly erose, then suddenly becoming thicker with convex trigones. Dioicous. Perianth absent, perigynium short, appeared as connate innermost and the second outward pair of bracts, bracts in 2-several leaf pairs, innermost pair smaller than the next outward, bracts with narrowly recurved margins, innermost bracts 4-lobate and connate with 2-3-lobed bracteole, or have not bracteole (in the latter case the second pair of bracts have it), the bracts of the next pair commonly 3-lobed, bracteole absent or present and bilobed, sometimes there is lanceolate short (and much smaller than in uppermost bracts) bracteole in 3-rd and 4-th circles of bracts.

Comment. By the distribution this is typical oroborealsubalpine East Asian taxon. The area of this species starts from northern Sikhote-Alin $\left(\mathrm{ca} .48^{\circ} \mathrm{N}\right)$ and nearly the same latitude in Sakhalin and then South Kurils. Southward it known in several localities in Korean Peninsula to Jeju-do and widely spreading to Japan (at least until Yakushima). Seems to be likely will be found in Northeast China (at least in Changbaishan). Basically, this species occurs on moderately moistened cliffs in subalpine and oroboreal belts of mountains. As exception, it was found in low part of mountain tundra belt in Iturup and central Sakhalin, at elevation 1300-1600 m a.s.l. However these habitats can be hardly called as true tundra and rather caused by strong wind regime near mountain peaks. Besides, the species may descend to mountain cool-temperate (broadleaved deciduous) forests in Korean Peninsula. In low elevation the species occurs in southern Kurils where prefers coastal cliffs with rather severe wind conditions that promote development of 'tundroid' vegetation in low elevation (Shikotan, Kunashir, Iturup Islands). The species prefers to occupy mesic to moist or, rarely, wet acidic (most commonly granite or andesite) cliffs and their open crevices. It evidently avoids shady places, although also do not survive in full sun.

The striking morphological characters of the species include at least locally papillose cuticle along leaf lobe margin, acute and crenulate lobes, sinus descending to $1 / 5-1 / 4$ of leaf length and leaf margin composed by thin-walled and sometimes erose cells with small, but distinct trigones. The species is somewhat related to widely distributed in East Asian Arctic and Hemiarctic and becoming much rarer southward G. concinnatum (not known in Korea, and sparsely occurring in Japan at least untill Gifu Pref.). G. faurianum differs from the latter in: 1) whitish colored plants mostly without brown coloration in living parts of leaves (versus common brownish to brown coloration in leaf middle of uppermost leaves in G. concinnatum), 2) strongly dorsiventrally compressed shoots (versus shoots vermicular or only slightly transversely elliptic in cross section), 3) cells along margin are thin-walled, and sometimes erose (versus cell walls moderately thickened and having large trigones and hardly erose), 4) leaf cuticle loosely papillose to almost smooth (versus cuticle constantly papillose at least in leaf lobe margins).

Lophozia ubayensis Steph. treated as synonym of G. corallioides by Kitagawa (1963) is in all ways identical to G. faurianum .

3. Gymnomitrion laceratum (Steph.) Horik. Acta Phytotaxonomica et Geobotanica 13: 212. 1943. (Fig. 2: C-L)

Basionym: Acolea lacerata Steph. Species Hepaticarum 6: 78. 1917.

Lectotype: 'Japonia', leg. Faurie (G00067201/15028!) (selected by J. Váňa, in herb.)

Description based on the type Acolea lacerata: Plants brownish, more or less rigid, with characteristically discolored leaf margins, forming merely dense patches brownish whitish in color, slightly dorsiventrally compressed, female branches (appears mostly as short ventral innovations) distinctly clavate and dorsiventrally compressed; plants freely ventrally branched, 200-400 $\mu \mathrm{m}$ wide, in female branches up to $700 \mu \mathrm{m}$ wide near archegonia. Rhizoids common to numerous, colorless, obliquely to erect spreading, united in unclear fascicles or separated. Leaves in well developed (but not female) branches $300-400 \times 300-370 \mu \mathrm{m}$, nearly ovate to ovate-rectangular, margin entire, divided by $\mathrm{V}$ - to $\gamma$-shaped sinus descending to $1 / 3-2 / 5(1 / 2)$ of leaf length into two triangular to slightly gibbous lobes. Midleaf cells $17-24$ $\times 13-17 \mu \mathrm{m}$, thin-walled, with moderate in size to large convex trigones; cells in apical part of the lobe very thickwalled, 7-10 $\mu \mathrm{m}$ in diameter (along margin), with lumen only 5-7 $\mu \mathrm{m}$ in diameter; cells along leaf margin very thickwalled, 11-16 $\mu \mathrm{m}$ in diameter with visible median lamina, never erose. Dioicous. Innermost bracts smaller than bracts in the second course, 4-7-lobed, with lobes narrow, with very prominent apiculate apices and sparsely dentate along

Figure 2 Gymnomitrion faurianum (Steph.) Horikawa: A, B - plant habit, from J-90-5-15 (VBGI). Gymnomitrion laceratum (Steph.) Horikawa: C - lectotype label $(\mathrm{G})$; D - bract apex, from lectotype $(\mathrm{G}) ; \mathrm{E}$ - underleaf apex, from lectotype $(\mathrm{G}) ; \mathrm{F}$ - leaf lobe apex, from lectotype $(\mathrm{G}) ; \mathrm{G}-$ leaf, from lectotype $(\mathrm{G}) ; \mathrm{H}, \mathrm{I}$ - plant habit, from lectotype $(\mathrm{G}) ; \mathrm{J}$ - leaf margin, from lectotype $(\mathrm{G}) ; \mathrm{K}$ - midleaf cells, from lectotype $(\mathrm{G}) ; \mathrm{L}-$ plant habit, from J-87-36-15 (VBGI). Scales: $\mathrm{a}-1 \mathrm{~mm}$, for A, H, I; a - 2 mm, for B, a - $400 \mu \mathrm{m}$, for L; b - $300 \mu \mathrm{m}$, for D, G; b - 200, for E; c - $50 \mu \mathrm{m}$, for F, J, K 

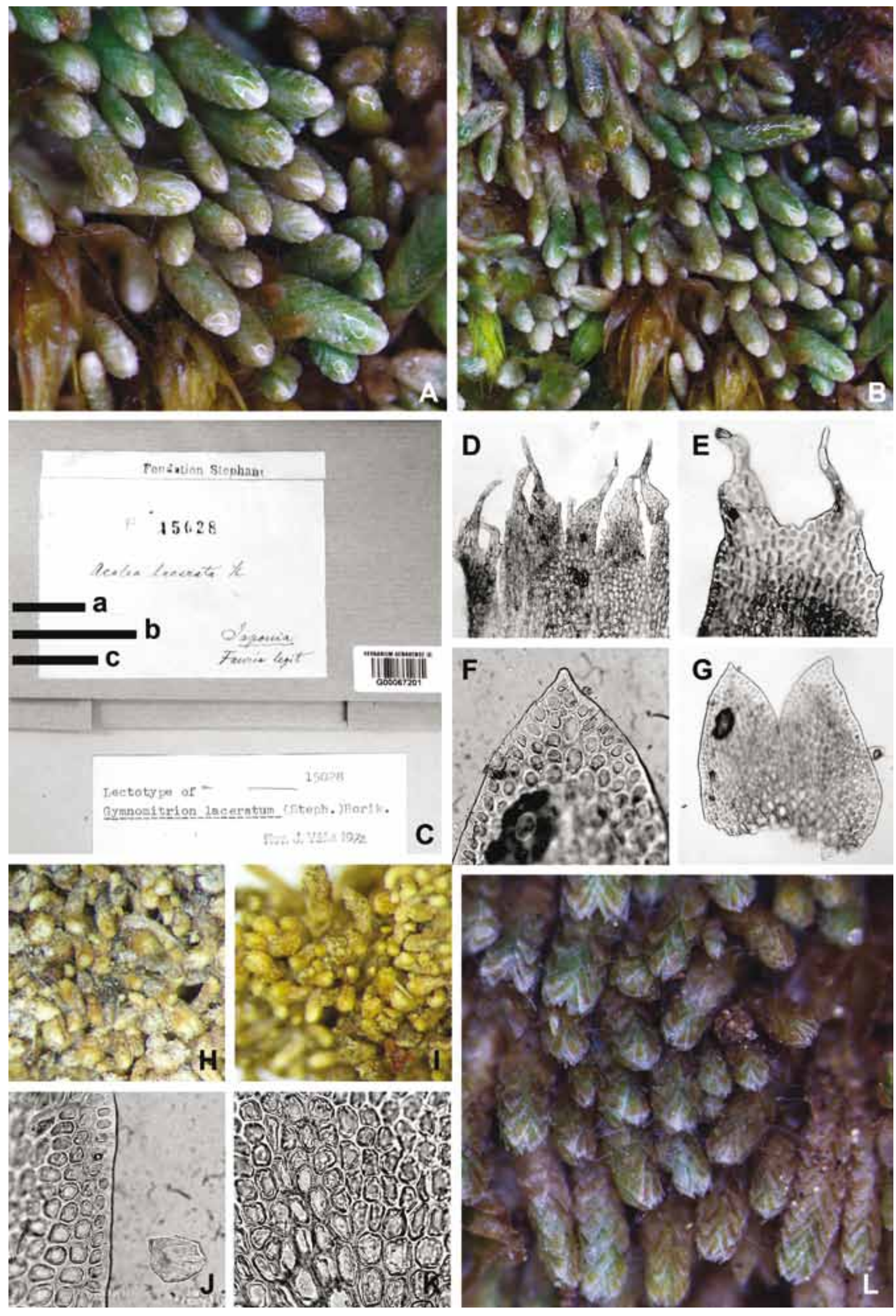
margin, connate for $1 / 3-1 / 2$ of the length with bilobed bracteole; innermost bract ring connate with the second course and form therefore the formation related to perigynium, the second bract course has 2-3-lobed bracts, with unlobed or bilobed bracteole.

Comments. A. Another specimen, regarded as possible isotype (G00067202/15027!) in G contains the plants quite similar to lectotype.

B. At the first look this species similar to $G$. faurianum due to slightly squarrose leaf lobe apices near branch apex. However it differs from the latter in 1) brownish plant color (only leaf margin is discolored), 2) narrower shoots, 3) distinctly clavate female branches, 4) nearly smooth cuticle, 5) cells along margin in leaf apices are strongly and subequally thickened, with concave trigones and never erose. The presence of underleaves is probably very rare case and cannot be used for reliable differentiation. At least I was not able to see them in plants of the type outside of areas adjacent to archegonia. Another morphological relatives of the taxon are G. concinnatum ( that differs in nearly constantly papillose leaf lobe margin cuticle, much thinner cell walls along crenulate margin and large convex trigones) and $G$. mucronulatum (N. Kitag.) N. Kitag. (that differs in very small leaf cells ranging in the midleaf from 8 to $10 \mu \mathrm{m}$ wide, small vermicular, not dorsiventrally compressed shoots and more shortly lobed leaves with sinus descending up to $1 / 5$ $1 / 4$ of leaf length).

\section{A key to Gymnomitrion taxa in extra-tropical Eastern Asia}

Extra-tropical Eastern Asia is treated here as covering the Russian Far East, Korean Peninsula, Japan and Chinese Heilongjiang, Jilin and Liaoning. The key does not include Marsupella apiculata Schiffn. (removed from Gymnomitrion recently) as well as 'perianthless Marsupella' and Apomarsupella recently transferred to Gymnomitrion but having the striking contrast in morphology with other bulk of taxa.

1. Leaves entire or loosely emarginate, ovate to transversely elliptic, cupped and commonly lacerate when flattened in the microscope slide Japanese-South Korean endemic species] G. noguchianum S. Hatt.

1. Leaves distinctly bilobed, although sometimes shortly so, mostly ovate, concave, rarely, or in some species commonly, lacerate when flattened in the microscope slide ................... 2

2. Leaf margin composed by thin-walled cells (rarely walls slightly thickened near leaf apex) with small to virtually absent trigones; commonly erose

.... 3

2. Leaf margin composed by thin- to thick-walled cells, with distinct trigones; never (or very rarely) erose ......................... 5

3. Plants terete, blackish to blackish brown and almost black, branches less than $0.3-0.4 \mathrm{~mm}$ in diameter, leaf margin distinctly crenulate, commonly not erose, composed by tangentially elongated cells (especially obvious near leaf base) [North Pacific].
3. Plants strongly dorsiventrally flattened (like thick ribbon), whitish to gray and pale brownish in color, leaf margin entire to crenulate, marginal cells never tangentially elongated

4. Plants not translucent when wet, leaf lobes rounded, entire, always appressed to the above situated leaf, and without trigones, leaf cuticle uniformly smooth, cells in the leaf margins virtually free of trigones, leaf margin very easily erose

G. corallioides Nees

4. Plants translucent when wet, lobes triangular (acute), crenulate, commonly squarrose (at least near shoot apices) and with cells having obvious trigones (sometimes also with thickened external wall), leaf cuticle finely papillose to almost smooth, cells along leaf margin with small, but distinct trigones (obvious near apices), leaf margin hardly to easily erose G. faurianum

5. Plants terete, blackish to blackish brown and almost black, branches less than $0.3-0.4 \mathrm{~mm}$ in diameter, leaf margin distinctly crenulate, composed by tangentially elongated cells (especially obvious in leaf base)

G. pacificum Grolle

5. Plants terete or not, mostly brown, reddish brown to yellowish and whitish, margin never composed by tangentially elongated cells, commonly entire (especially near the base) ..

6. Shoots less than $0.35 \mathrm{~mm}$ in diameter, midleaf cells very small, ca. $8 \times 8 \mu \mathrm{m}$, leaves bilobed not deeper than $1 / 4$ of leaf length [Japanese endemic species]

G. mucronulatum (N. Kitag.) N. Kitag.

6. Shoots wider than $0.4 \mathrm{~mm}$ in diameter, midleaf cells more than $10 \mu \mathrm{m}$ wide, leaves bilobed to $1 / 5-1 / 4$ of leaf length (then lobe margin cells cuticle distinctly papillose) or to $2 / 5$ of leaf length (then cuticle smooth)

7. Lobe marginal cells with distinctly papillose cuticle, leaves bilobed to $1 / 5-1 / 4$ of leaf length, margin crenulate, cells along leaf margin thin- to slightly thick-walled, with trigones large and convex ....... G. concinnatum (Lightf.) Corda

7. Lobe marginal cells with smooth cuticle, leaves bilobed for $1 / 4-2 / 5$ of leaf length, margin entire, cells along leaf margin strongly thick-walled, with moderate to large, but uniformly concave trigones ....... G. laceratum (Steph.) Horik.

\section{Selected specimens examined}

Comment. Only one specimen per each locality is cited. Type specimens cited above and are not included in this list. Before collection date I provide data on vegetation belts basing on the following acronyms in bold: A - alpine belt, commonly covered mountain tundra in the most extent, $\mathrm{C}$ - crooked forest belt or zone, that means domination Pinus pumila and Alnus fruticosa also with large areas occupied by gravelly barrens, $\mathrm{F}$ - oroboreal coniferous forest, BF broadleaved forests, $\mathrm{H}$ - heathlands (formation similar to alpine tundra, but distributed in low elevation and formed mainly due to wind regime, but not temperature characters and includes a lot of floristic elements alien to true tundra). Name of collectors given in full with the exception for VB (= V.A. Bakalin).

Figure 3 Gymnomitrion concinnatum (Lightf.) Corda: A, C-F - lobe apex; B, G - leaf margin (A, B - from Mag-23-3-13; C, D, E - from Mag-1925-13; F, G - from Kh-37-2-13, all from VBGI). Gymnomitrion corallioides Nees: H, K, M, O - leaf margin; I, J, L, N, P - lobe apex (H, I - from Kh-36-31-13; J, K, L - from Mag-19-46-13; M, N - from Mag-27-3-14; O, P - from Mag-30-11-11, all from VBGI). Gymnomitrion faurianum (Steph.) Horikawa: Q, S, V - leaf margin; R, T, U, W, X - lobe apex (Q, R - from J-90-5-15; S, T - from K-66-13-07; U, V - from Kh-41-4-13; W - from Kor-6-33-11; X - from Kor-11-11-11, all from VBGI). Scale: a - $100 \mu \mathrm{m}$, for A-XK 

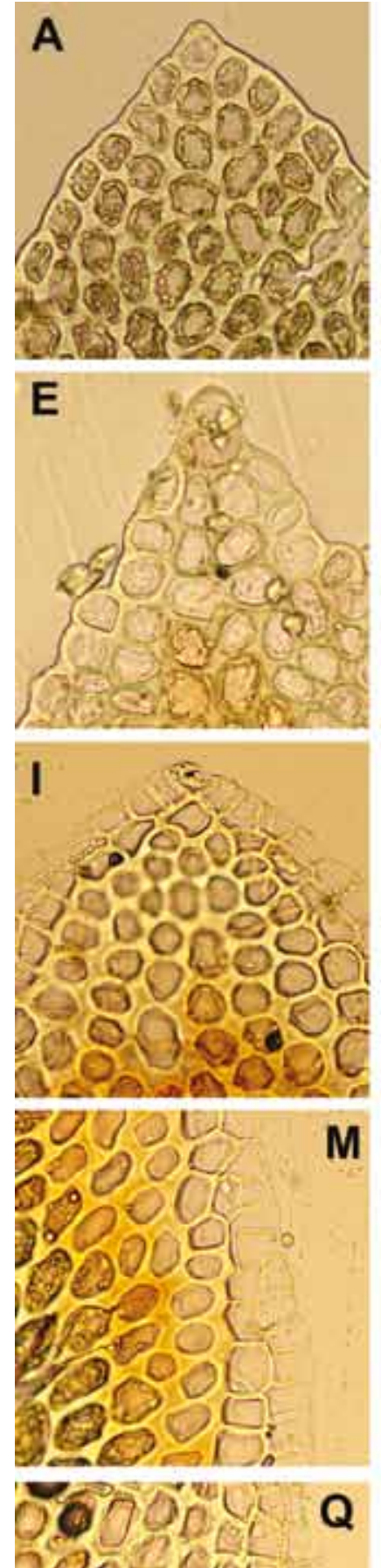

200.01

3000 .

a. 0 le

$000 \%$

1009:

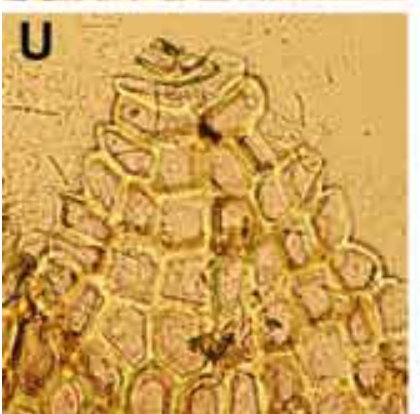

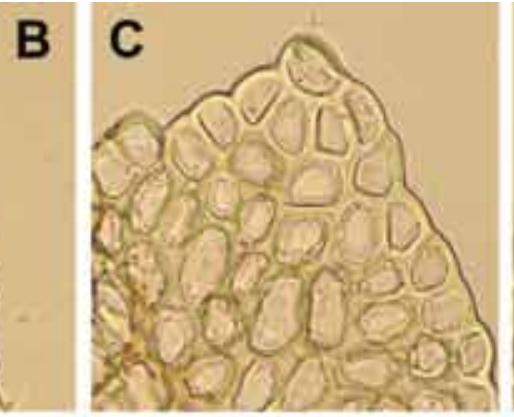
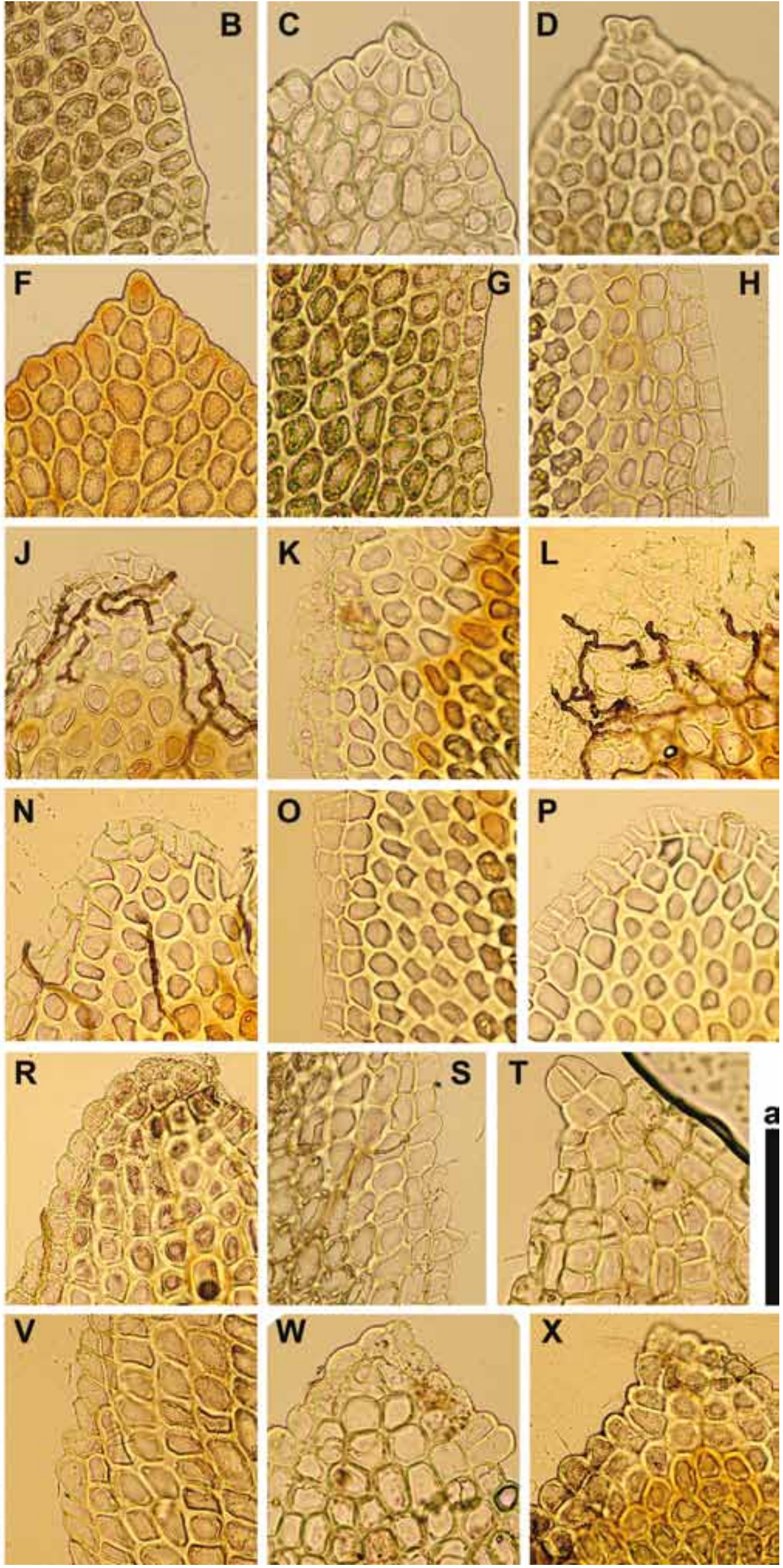
Gymnomitrion concinnatum: JAPAN, GIFU PREF., Ontake Mt. $2800 \mathrm{~m}$ alt. (C), 19.IX.1969 Mizutani M. 206 (NICH-103671); IWATE PREF., Iitoyayama Mt. (F?), 26.VII.1965 Ohba T. 1-109 (NICH-81621). RUSSIA, KAMCHATKA TERRITORY, Alnej Vlc. $\left(56^{\circ} 39^{\prime} \mathrm{N}\right.$ $159^{\circ} 29^{\prime} \mathrm{E}$ ), $1000 \mathrm{~m}$ alt. (A) 13.IX.2004 VB, k-133-64-04 (VBGI); (56 $\left.39^{\prime} \mathrm{N} 159^{\circ} 29^{\prime} \mathrm{E}\right), 1400 \mathrm{~m}$ alt. (A) 14.IX.2004 VB, k-134-33-04 (VBGI); Anaun Vlc. (56 $\left.08^{\circ} \mathrm{N} 158^{\circ} 56^{\prime} \mathrm{E}\right)$, $1300 \mathrm{~m}$ alt. (A) 09.IX.2004 VB, k-130-25-04 (VBGI); Dygeren Range $\left(55^{\circ} 54^{\prime} \mathrm{N} 158^{\circ} 46^{\prime} \mathrm{E}\right), 1170 \mathrm{~m}$ alt. (A)

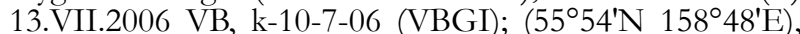
$1361 \mathrm{~m}$ alt. (A) 13.VII.2006 VB, k-11-4-06 (VBGI); Esso $\left(55^{\circ} 59^{\prime} \mathrm{N} 158^{\circ} 37^{\prime} \mathrm{E}\right), 1150 \mathrm{~m}$ alt. (C) 11.VII.2006 VB, k-91-06 (VBGI); Kamchatsky Mys Range $\left(56^{\circ} 08^{\prime} \mathrm{N} 162^{\circ} 50^{\prime} \mathrm{E}\right)$, $668 \mathrm{~m}$ alt. (A) 06.VI.2006 VB, k-6-11-06 (VBGI); Karaginskiy Island ( $\left.58^{\circ} 57^{\prime} \mathrm{N} 164^{\circ} 15^{\prime} \mathrm{E}\right), 380 \mathrm{~m}$ alt. (C) 03.VIII.2005 VB, k-26-16-05 (VBGI); (58 57'N 164ำ'E), 392 m alt. (C) 03.VIII.2005 VB, k-27-2-15 (VBGI); (58 $\left.58^{\circ} \mathrm{N} 164^{\circ} 16^{\prime} \mathrm{E}\right)$, $602 \mathrm{~m}$ alt. (A) 01.VIII.2005 VB, k-20-14-15 (VBGI); Klyuchevskoy Dol $\left(57^{\circ} 03^{\prime} \mathrm{N} 161^{\circ} 45^{\prime} \mathrm{E}\right)$, (A) 20.VIII.2004 VB, s.n. (VBGI); Kopkan River $\left(56^{\circ} 25^{\prime} \mathrm{N} 159^{\circ} 13^{\prime} \mathrm{E}\right), 1400 \mathrm{~m}$ alt. (A) 17.IX.2004 VB, k-137-23-04 (VBGI); Mednyj Island $\left(54^{\circ} 45^{\prime} \mathrm{N} 167^{\circ} 36^{\prime} \mathrm{E}\right), 245 \mathrm{~m}$ alt. (H) 02.VII.2004 VB, k-46-1-04 (VBGI); (54 $\left.47^{\prime} \mathrm{N} 167^{\circ} 35^{\prime} \mathrm{E}\right), 50 \mathrm{~m}$ alt. (H) 02.VII.2004 VB, k-53-12-04 (VBGI); Palana Hot Springs $\left(58^{\circ} 50^{\prime} \mathrm{N} 161^{\circ} 20^{\prime} \mathrm{E}\right), 1300 \mathrm{~m}$ alt. (A) 12.VII.2003 VB, k37-10a-03 (VBGI); (58 $\left.50^{\prime} \mathrm{N} 161^{\circ} 20^{\prime} \mathrm{E}\right), 550 \mathrm{~m}$ alt. (A) 11.VII.2003 VB, k-35-1-03 (VBGI); (58 $\left.50^{\prime} \mathrm{N} 161^{\circ} 20^{\prime} \mathrm{E}\right)$, $650 \mathrm{~m}$ alt. (A) 11.VII.2003 VB, k-33-10b-03 (VBGI); Plosky Khrebet Range $\left(52^{\circ} 50^{\prime} \mathrm{N} 157^{\circ} 40^{\prime} \mathrm{E}\right), 500 \mathrm{~m}$ alt. (C) 08.VI.2003 VB, k-19-4-03 (VBGI); Shanuch borough $\left(55^{\circ} 40^{\prime} \mathrm{N} 157^{\circ} 40^{\prime} \mathrm{E}\right), 900 \mathrm{~m}$ alt. (C) 14.IX.2002 VB, k-5034-02 (VBGI); Tolbachik Volcano $\left(55^{\circ} 49^{\prime} \mathrm{N} 160^{\circ} 20^{\prime} \mathrm{E}\right)$, $1260 \mathrm{~m}$ alt. (A) 21.08.2006 Czernyadjeva I. s.n. (VBGI); $\left(55^{\circ} 49^{\prime} \mathrm{N} 160^{\circ} 20^{\prime} \mathrm{E}\right)$, (A) 19.VIII.2006 Czernyadjeva I. s.n. (VBGI); Ushkovsky Vlc. $\left(56^{\circ} 11^{\prime} \mathrm{N} 160^{\circ} 21^{\prime} \mathrm{E}\right), 1018 \mathrm{~m}$ alt. (A) 21.VII.2003 VB, k-46-1-03 (VBGI); KHABAROVSK TERRITORY, Lanzhinsky Mts. $\left(59^{\circ} 25^{\prime} \mathrm{N} 143^{\circ} 30^{\prime} \mathrm{E}\right), 444$ $\mathrm{m}$ alt. (C) 21.VII.2008 VB, kh-27-14-08 (VBGI); (59 $26^{\prime} \mathrm{N}$ $143^{\circ} 28^{\prime} \mathrm{E}$ ), $200 \mathrm{~m}$ alt. (C) 27.VII.2008 VB, kh-44-10-08 (VBGI); $\left(59^{\circ} 26^{\prime} \mathrm{N} 143^{\circ} 28^{\prime} \mathrm{E}\right), 220 \mathrm{~m}$ alt. (C) 27.VII.2008 VB, kh-46-8-08 (VBGI); (59 $\left.29^{\prime} \mathrm{N} 143^{\circ} 23^{\prime} \mathrm{E}\right), 357 \mathrm{~m}$ alt. (C) 22.VII.20008 VB, kh-31-5-08 (VBGI); Tardoki-Yani Range $\left(48^{\circ} 53^{\prime} \mathrm{N} 138^{\circ} 03^{\prime} \mathrm{E}\right), 2010 \mathrm{~m}$ alt. (A) 22.VIII.2013 VB, kh-36-48-13 (VBGI); (48 $\left.54^{\prime} \mathrm{N} 138^{\circ} 03^{\prime} \mathrm{E}\right), 1850 \mathrm{~m}$ alt. (A) 23.VIII.2013 VB, kh-39-5-13 (VBGI); (48 $54^{\prime} \mathrm{N}$ $138^{\circ} 03^{\prime} \mathrm{E}$ ), $2090 \mathrm{~m}$ alt. (A) 23.VIII.2013 VB, kh-37-2-13 (VBGI); MAGADAN PROVINCE, Annachag Range $\left(62^{\circ} 466^{\prime} \mathrm{N} 149^{\circ} 21^{\prime} \mathrm{E}\right), 1270 \mathrm{~m}$ alt. (A) $29 . \mathrm{VII} .2014 \mathrm{VB}$, mag24-14-14 (VBGI); (62 $\left.46^{\prime} \mathrm{N} 149^{\circ} 21^{\prime} \mathrm{E}\right), 1270 \mathrm{~m}$ alt. (A) 29.VII.2014 VB, mag-24-29-14 (VBGI); Kamennyy Khrebet Range $\left(59^{\circ} 47^{\prime} \mathrm{N} 149^{\circ} 40^{\prime} \mathrm{E}\right), 400 \mathrm{~m}$ alt. (C) 17.VI.2010 $\mathrm{VB}$, mag-23-25-10 (VBGI); $\left(59^{\circ} 48^{\prime} \mathrm{N} 149^{\circ} 40^{\prime} \mathrm{E}\right), 693 \mathrm{~m}$ alt. (A) 07.VIII.2013 VB, mag-19-25-13 (VBGI); $\left(59^{\circ} 48^{\prime} \mathrm{N}\right.$ $\left.149^{\circ} 41^{\prime} \mathrm{E}\right), 880 \mathrm{~m}$ alt. (A) 10.VIII.2013 VB, mag-25-7-13 (VBGI); (59 $\left.49^{\circ} \mathrm{N} 149^{\circ} 42^{\prime} \mathrm{E}\right), 901 \mathrm{~m}$ alt. (A) 09.VIII.2013 VB, mag-23-2-13 (VBGI); Kilganskiye Gory Mts. $\left(61^{\circ} 12^{\prime} \mathrm{N}\right.$ $153^{\circ} 54^{\prime} \mathrm{E}$ ), $1060 \mathrm{~m}$ alt. (C) 10.VIII.2012 VB, mag-32-16-12 (VBGI); (61 $\left.{ }^{\circ} 12^{\prime} \mathrm{N} 153^{\circ} 59^{\prime} \mathrm{E}\right), 1400 \mathrm{~m}$ alt. (A) 09.VIII.2012 VB, mag-28-16-12 (VBGI);Magadan city $\left(59^{\circ} 31^{\prime} \mathrm{N}\right.$ $\left.150^{\circ} 49^{\prime} \mathrm{E}\right), 350 \mathrm{~m}$ alt. (C) 11.VIII.2011 VB, mag-61-1-11 (VBGI); (59 $\left.31^{\prime} \mathrm{N} 150^{\circ} 49^{\prime} \mathrm{E}\right), 350 \mathrm{~m}$ alt. (A) 11.VIII.2011 VB, mag-61-34-11 (VBGI); (59 $\left.34^{\circ} \mathrm{N} 150^{\circ} 39^{\prime} \mathrm{E}\right), 200 \mathrm{~m}$ alt. (C) 08.VIII.14 VB, mag-33-18-14 (VBGI); $\left(59^{\circ} 34^{\prime} \mathrm{N}\right.$ $150^{\circ} 39^{\prime} \mathrm{E}$ ), $296 \mathrm{~m}$ alt. (C) 16.VI.2010 VB, mag-20-34-10 (VBGI); Ol'skoye Plateau $\left(60^{\circ} 39^{\prime} \mathrm{N} 151^{\circ} 25^{\prime} \mathrm{E}\right), 1200 \mathrm{~m}$ alt. (A) 09.VIII.2014 VB, mag-55-3-11 (VBGI); $\left(60^{\circ} 39^{\prime} \mathrm{N}\right.$ 151 ${ }^{\circ} 26^{\prime} \mathrm{E}$ ), $1150 \mathrm{~m}$ alt. (A) 06.VIII.2014 VB, mag-30-2-14 (VBGI); $\left(60^{\circ} 40^{\prime} \mathrm{N} 151^{\circ} 21^{\prime} \mathrm{E}\right), 1106 \mathrm{~m}$ alt. (A) 23.VII.2011 VB, mag-28-8-11 (VBGI); Tenkinsky District $\left(62^{\circ} 07^{\prime} \mathrm{N}\right.$ $\left.148^{\circ} 57^{\prime} \mathrm{E}\right), 1600 \mathrm{~m}$ alt. (A) 18.VII.2006 Sinelnikova N. $23 \mathrm{f}$
(VBGI); Tuonnakh Range $\left(63^{\circ} 16^{\prime} \mathrm{N} 151^{\circ} 03^{\prime} \mathrm{E}\right), 1244 \mathrm{~m}$ alt. (A) 23.VII.2011 VB, mag-27-4-11 (VBGI); (631' $\mathrm{N}$ $\left.151^{\circ} 03^{\prime} \mathrm{E}\right), 1244 \mathrm{~m}$ alt. (A) 26.VII.2011 VB, mag-38-32-11 (VBGI); (63ำ $\left.17^{\prime} \mathrm{N} 151^{\circ} 03^{\prime} \mathrm{E}\right), 1312 \mathrm{~m}$ alt. (A) 25.VII.2011 VB, mag-35-20-11 (VBGI); (6318'N 151으'E), $1960 \mathrm{~m}$ alt. (A) 24.VII.2011 VB, mag-33-6-11 (VBGI); REPUBIC OF YAKUTIYA, Toko Lake 'E), $1800 \mathrm{~m}$ alt. (A) 27.VIII.1911 Prokhorov N. \& O. Kuzeneva s.n. (VBGI); SAKHALIN PROVINCE, Chamga Mt. $\left(50^{\circ} 45^{\prime} \mathrm{N} 143^{\circ} 18^{\prime} \mathrm{E}\right), 1375 \mathrm{~m}$ alt. (A) 15.VIII.2006 VB, s-27-5a-06 (VBGI); Iturup Island $\left(44^{\circ} 53^{\prime} \mathrm{N} 147^{\circ} 27^{\prime} \mathrm{E}\right), 1335 \mathrm{~m}$ alt. (H) 09.VIII. $2007 \mathrm{VB}, \mathrm{k}-15-$

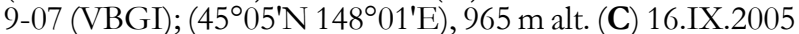
VB, k-59-4-05 (VBGI); (4506'N 148 01'E), $1114 \mathrm{~m}$ alt. (C) 16.IX.2005 VB, k-58-11-05 (VBGI); Kunashir Island $\left(44^{\circ} 21^{\prime} \mathrm{N} 146^{\circ} 15^{\prime} \mathrm{E}\right), 1500 \mathrm{~m}$ alt. (A) 14.IX.2006 VB, k57-11c-06 (VBGI); (442 $\left.27^{\prime} \mathrm{N} 146^{\circ} 07^{\prime} \mathrm{E}\right), 1100 \mathrm{~m}$ alt. (C) 29.VIII.2006 VB, k-38-1b-06 (VBGI); $\left.44^{\circ} 28^{\prime} \mathrm{N} 146^{\circ} 08^{\prime} \mathrm{E}\right)$, $1300 \mathrm{~m}$ alt. (C) 29.VIII.2006 VB, k-39-3-06 (VBGI); Paramushir Island $\left(50^{\circ} 42^{\prime} \mathrm{N} 146^{\circ} 08^{\prime} \mathrm{E}\right), 50 \mathrm{~m}$ alt. (C) 20.VII.2004 VB, k-79-6-04 (VBGI). U.S.A., ALASKA, Adak Island (H) 15.06.1975 Davison P. 3633 (VBGI).

Gymnomitrion corallioides: RUSSIA, KAMCHATKA TERRITORY, Alnej Vlc. $\left(56^{\circ} 39^{\prime} \mathrm{N} 159^{\circ} 29^{\prime} \mathrm{E}\right), 1700 \mathrm{~m}$

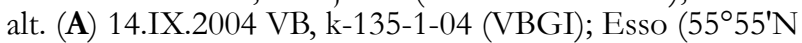
$158^{\circ} 40^{\prime} \mathrm{E}$ ), $1000 \mathrm{~m}$ alt. (A) 09.IX.2003 VB, k-106-4-03

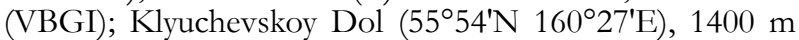
alt. (A) 17.VIII.2004 Czernyadjeva I. s.n. (VBGI); Kronotsky Peninsula, $600 \mathrm{~m}$ alt. (A) 19.VIII.1981 Mikulin A. s.n. (VBGI); Kronotsky Peninsula, $600 \mathrm{~m}$ alt. (H) 1979 Mikulin A. s.n. (VBGI); Mednyj Island (54. $\left.43^{\prime} \mathrm{N} 167^{\circ} 40^{\prime} \mathrm{E}\right), 152$ $\mathrm{m}$ alt. (H) 01.VII.2004 VB, k-28-8-04 (VBGI); $\left(54^{\circ} 43^{\prime} \mathrm{N}\right.$ $\left.167^{\circ} 40^{\prime} \mathrm{E}\right), 247 \mathrm{~m}$ alt. (H) 01.VII.2004 VB, k-29-2-04 (VBGI); Tolbachik Volcano $\left(55^{\circ} 49^{\prime} \mathrm{N} 160^{\circ} 20^{\prime} \mathrm{E}\right), 1260 \mathrm{~m}$ alt. (A) 21.08.2006 Czernyadjeva I. s.n. (VBGI); $\left(55^{\circ} 49^{\prime} \mathrm{N}\right.$ $160^{\circ} 20^{\prime} \mathrm{E}$ ), $1344 \mathrm{~m}$ alt. (A) 22.VIII.2006 Czernyadjeva I. s.n. (VBGI); Ushkovsky Vlc. $\left(56^{\circ} 11^{\prime} \mathrm{N} 160^{\circ} 22^{\prime} \mathrm{E}\right), 1205$ $\mathrm{m}$ alt. (A) 21.VII.2003 VB, k-43-1b-03 (VBGI); $\left(56^{\circ} 11^{\prime} \mathrm{N}\right.$ $160^{\circ} 23^{\prime} \mathrm{E}$ ), $1034 \mathrm{~m}$ alt. (A) 23.VII.2003 VB, k-56-5b-03 (VBGI); $\left(56^{\circ} 08^{\prime} \mathrm{N} 160^{\circ} 24^{\prime} \mathrm{E}\right), 1900 \mathrm{~m}$ alt. (A) 25.VII.2003 VB, k-64-4a-03 (VBGI); KHABAROVSK TERRITORY, Lanzhinsky Mts. $\left(29^{\circ} 25^{\prime} \mathrm{N} 143^{\circ} 30^{\prime} \mathrm{E}\right), 321 \mathrm{~m}$ alt. (C) 25.VII.2008 VB, kh-37-6-08 (VBGI); Tardoki-Yani Range $\left(48^{\circ} 53^{\prime} \mathrm{N} 138^{\circ} 03^{\prime} \mathrm{E}\right), 2010 \mathrm{~m}$ alt. (A) 22.VIII.2013 VB, kh-36-12-13 (VBGI); (48 $\left.53^{\prime} \mathrm{N} 138^{\circ} 03^{\prime} \mathrm{E}\right), 2010 \mathrm{~m}$ alt. (A) 22.VIII.2013 VB, kh-36-31-13 (VBGI); MAGADAN PROVINCE, Annachag Range $\left(62^{\circ} 09^{\prime} \mathrm{N} 149^{\circ} 22^{\prime} \mathrm{E}\right)$, $1330 \mathrm{~m}$ alt. (A) 30.VII.2014 VB, mag-27-3-14 (VBGI); $\left(62^{\circ} 10^{\prime} \mathrm{N} 149^{\circ} 18^{\prime} \mathrm{E}\right), 1600 \mathrm{~m}$ alt. (A) 29.VII.2014 VB, mag26-21-14 (VBGI); Kamennyy Khrebet Range $\left(59^{\circ} 48^{\prime} \mathrm{N}\right.$ $149^{\circ} 41^{\prime} \mathrm{E}$ ), $693 \mathrm{~m}$ alt. (A) 07.VIII.2013 VB, mag-19-46-13 (VBGI); Ol'skoye Plateau $\left(60^{\circ} 39^{\prime} \mathrm{N} 151^{\circ} 26^{\prime} \mathrm{E}\right), 1150 \mathrm{~m}$ alt. (A) 11.VII.2010 VB, mag-11-37-10 (VBGI); $\left(60^{\circ} 39^{\prime} \mathrm{N}\right.$ $\left.151^{\circ} 26^{\prime} \mathrm{E}\right), 1150 \mathrm{~m}$ alt. (A) 06.VIII.2014 VB, mag-30-37-14 (VBGI); (60³9'N 151 $\left.{ }^{\circ} 27^{\prime} \mathrm{E}\right), 1166 \mathrm{~m}$ alt. (A) 09.VIII.2011 VB, mag-54-3-11 (VBGI); Tuonnakh Range $\left(63^{\circ} 16^{\prime} \mathrm{N}\right.$ $151^{\circ} 03^{\prime} \mathrm{E}$ ), $1106 \mathrm{~m}$ alt. (A) 23.VII.2011 VB, mag-28-4-11 (VBGI); (63ำ $\left.17^{\prime} \mathrm{N} 151^{\circ} 04^{\prime} \mathrm{E}\right), 1312 \mathrm{~m}$ alt. (A) 25.VII.2011

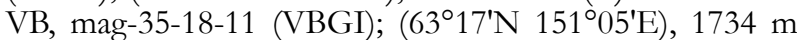
alt. (A) 24.VII.2011 VB, mag-32-4-11 (VBGI); $\left(63^{\circ} 18^{\prime} \mathrm{N}\right.$ 151 ${ }^{\circ} 06^{\prime} \mathrm{E}$ ), $1960 \mathrm{~m}$ alt. (A) 24.VII.2011 VB, mag-33-411 (VBGI); MURMANSK PROVINCE, Khibiny Mts. $\left(67^{\circ} 38^{\prime} \mathrm{N} 33^{\circ} 37^{\prime} \mathrm{E}\right), 870 \mathrm{~m}$ alt. (A) 21.VI.1981 Gambaryan S.K., s.n. (VBGI); SAKHALIN PROVINCE, Kunashir Island $\left(44^{\circ} 21^{\prime} \mathrm{N} 146^{\circ} 15^{\prime} \mathrm{E}\right), 1500 \mathrm{~m}$ alt. (A) 14.IX.2006 VB,

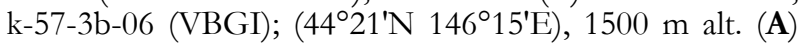
14.IX.2007 VB, k-57-6a-06 (VBGI).

Gymnomitrion faurianum: JAPAN (all cited here specimens for Japan, with exclusion of that collected by Bakalin, were before identified as $G$. corallioides), HOKKAIDO 
PREF., Rishiri Mt., 1200-1300 m alt. (C), 10.VIII.1954 Fukuhara M. 310 (NICH-232481); $1700 \mathrm{~m}$ alt. (C), 13.VIII.1971 Iwatsuki Z. 1766 (NICH-122232); IWATE PREF., Waka-machi 600-1000 m alt. (F), VIII.1969 Higuchi T. s.n. (NICH-101038); KAGOSHIMA PREF., Yakushima: Mivanoura Mt. $1700 \mathrm{~m}$ alt. (F), 24.VII.1951 Amakawa T. 22 (NICH-57422); NAGANO PREF., Ontake Mt. 2100 m alt., 23.VIII.1973 Yamada K. 4095 (NICH-234811), Kongo Mt. $960 \mathrm{~m}$ alt. (F), 24.V.1981 Honma K. 7279 (NICH-181609); TOYAMA PREF., Joodoyama 2600-2800 $\mathrm{m}$ alt. (C), 15.VIII.1959 Inoue H. 8637 (NICH-46967); Tateyama Mt. 2600-2872 m alt. (C), 20.VIII.1973 Yoshimura I. and K. Yamada 90 (NICH-144291); Jodo-yama 2600-2870 m alt. (C), 20.VIII.1973 Yamada K. s.n. (NICH149278); YAMAGATA PREF., Fukura-guchi 1000-1300 m alt. (F), 05.VIII.1959 Mizutani M. s.n. (NICH-75389), Senjo-ga-dake Mt. $\left(35^{\circ} 43^{\prime} 12^{\prime \prime} \mathrm{N} 138^{\circ} 11^{\prime} 01^{\prime \prime E}\right), 3033 \mathrm{~m}$ alt. (C), 2.X.2015 VB J-90-5-15 (VBGI). REPUBLIC OF KOREA, Gangwon-do $\left(38^{\circ} 08^{\prime} \mathrm{N} 128^{\circ} 28^{\prime} \mathrm{E}\right), 908 \mathrm{~m}$ alt. (BF) 11.X.2010 Choi S.S., s.n. (VBGI); Seorak Mt. $\left(38^{\circ} 08^{\prime} \mathrm{N}\right.$ $128^{\circ} 26^{\prime} \mathrm{E}$ ), $1000 \mathrm{~m}$ alt. (BF) 11.V.2011 VB, kor-6-33-11 (VBGI); $\left(38^{\circ} 08^{\prime} \mathrm{N} 128^{\circ} 28^{\prime} \mathrm{E}\right), 900 \mathrm{~m}$ alt. (BF) 13.05.2011 VB, kor-11-11-11 (VBGI); (38 $\left.07^{\circ} \mathrm{N} 128^{\circ} 26^{\prime} \mathrm{E}\right) 1449 \mathrm{~m}$ alt., (BF) 21.IX.2009 S.S. Choi, 5148 (JNU); $\left(38^{\circ} 07^{\prime} \mathrm{N} 128^{\circ} 28^{\prime} \mathrm{E}\right)$ $1710 \mathrm{~m}$ alt., (F) 21.IX.2009 S.S. Choi, 5206 (JNU); Jeju-do $\left(33^{\circ} 22^{\prime} \mathrm{N} 126^{\circ} 32^{\prime} \mathrm{E}\right) 1916 \mathrm{~m}$ alt, (F) 08.VIII.2010 S.S. Choi, 7759 (JNU); (N3321'51.0" E126³1'42.9"), 1814 m alt., (F) 07.IX.2012, S.S. Choi 120827 (JNU). RUSSIA, KHABAROVSK TERRITORY, Tardoki-Yani Range $\left(48^{\circ} 54^{\prime} \mathrm{N} 138^{\circ} 00^{\prime} \mathrm{E}\right), 1884 \mathrm{~m}$ alt. (C) 25.VIII.2013 VB, kh-41-4-13 (VBGI); SAKHALIN PROVINCE, Chamga Mt. $\left(50^{\circ} 45^{\prime} \mathrm{N} 143^{\circ} 18^{\prime} \mathrm{E}\right), 1300 \mathrm{~m}$ alt. (C) 11.IX.2009 VB, s-61-24-09 (VBGI); $\left(50^{\circ} 45^{\prime} \mathrm{N} 143^{\circ} 18^{\prime} \mathrm{E}\right), 1375 \mathrm{~m}$ alt. (A) 15.VIII.2006 VB, s-27-5a-06 (VBGI); Iturup Island (44 $50^{\circ} \mathrm{N}$ $147^{\circ} 20^{\prime} \mathrm{E}$ ), $1600 \mathrm{~m}$ alt. (A) 11.VIII.2007 VB, k-18-1-07

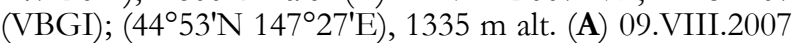
VB, k-15-10-07 (VBGI), (4526'46"N 148 49'23"E), 350 $\mathrm{m}$ alt. (C), 17.IX.2015 VB K-78-3-15 (VBGI); Kunashir Island $\left(43^{\circ} 53^{\prime} \mathrm{N} 145^{\circ} 27^{\prime} \mathrm{E}\right), 30 \mathrm{~m}$ alt. (H) 06.IX.2006 VB, k-46-16-06 (VBGI); $\left(44^{\circ} 27^{\prime} \mathrm{N} 146^{\circ} 07^{\prime} \mathrm{E}\right), 1100 \mathrm{~m}$ alt. (C) 29.VIII.2006 VB, k-38-1c-06 (VBGI); (44⒉ $\left.28^{\prime} \mathrm{N} 146^{\circ} 08^{\prime} \mathrm{E}\right)$, $1300 \mathrm{~m}$ alt. (C) 29.VII.2006 VB, k-39-6b-06 (VBGI); Shikotan Island $\left(43^{\circ} 45^{\prime} \mathrm{N} 146^{\circ} 43^{\prime} \mathrm{E}\right), 144 \mathrm{~m}$ alt. (H) 03.IX.2007 VB, k-60-6-07 (VBGI); (434ㅇ' $\left.146^{\circ} 43^{\prime} \mathrm{E}\right), 300 \mathrm{~m}$ alt. $(\mathbf{H})$ 26.VIII.2007 VB, k-45-20-07 (VBGI); (43ํำ'N 146²4'E),
$320 \mathrm{~m}$ alt. (H) 25.VIII.2007 VB, k-42-27-07 (VBGI); $\left(43^{\circ} 51^{\prime} \mathrm{N} 146^{\circ} 47^{\prime} \mathrm{E}\right), 150 \mathrm{~m}$ alt. (H) 06.IX.2007 VB,

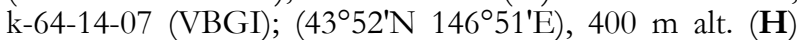

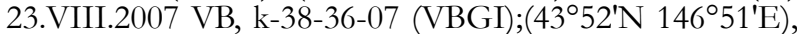
$400 \mathrm{~m}$ alt. (F) 08.IX.2007 VB, k-66-13-07 (VBGI); $30 \mathrm{~m}$ alt. (F) 24.VII.2010 Barkalov V.Yu., s.n. (VBGI).

\section{ACKNOWLEDGEMENTS}

I am sincerely grateful to curators of JNU, NICH, STR and $G$ for kind permission to work in these herbaria and providing necessary facilities for the work. I am also grateful to anonymous reviewers provided valuable comments and suggestions. The study was supported by the Russian Foundation for Basic Researches (grant 15-04-20101).

\section{LITERAT URE CITED}

Bakalin, V.A. 2015. Tardoki-Yani Range (North Sikhote-Alin, Pacific Russia) - the largest southern refugium of arcticalpine liverwort flora in East Asia. Arctoa 24:314-326.

Bakalin, V.A., V.Ya. Cherdantseva, M.S. Ignatov, E.A. Ignatova \& T.I. Nyushko 2009. Bryophyte flora of the South Kuril Islands (East Asia). Arctoa 18:69-114.

Bakalin, V.A., O.Yu. Pisarenko, V.Ya. Cherdantseva, P.V. Krestov, M.S. Ignatov \& E.A. Ignatova 2012. Bryophytes of Sakhalin. Izdatel'stvo Morskogo Universiteta, Vladivostok, 304 pp. (in Russian). [Бакалин В.А., Писаренко О.Ю., Черданцева В.Я., Крестов П.В., Игнатов М.С., Игнатова Е.А.. 2012. Брифмора Сахалина / реА. В.А. Бакалин. ВАадивосток: ИзА-во Морского гос. ун-та. 304 с.].

Grolle, R. 1976. Verzeichnis der Lebermoose Europas und benachbarter Gebiete. Feddes Repertorium 87(3-4): 171-279.

Kitagawa, N. 1963. A revision of the family Marsupellaceae of Japan. The Journal of Hattori Botanical Laboratory 26: 76-118.

Yamada, K. \& D.-M. Choe 1997. A checklist of Hepaticae and Anthocerotae in the Korean peninsula. The Journal of Hattori Botanical Laboratory 81: 175-242.

Yamada, K. \& Z. Iwatsuki 2006. Catalog of the hepatics of Japan. The Journal of Hattori Botanical Laboratory 99:1106. 